OPEN ACCESS

Edited by:

Paula Macarena Toro-Mujica, Universidad de O'Higgins, Chile

Reviewed by:

Guillermo Jiménez-Ferrer, The South Border College (ECOSUR), Mexico

Yosra Ahmed Soltan,

Alexandria University, Egypt

*Correspondence: Jacobo Arango j.arango@cgiar.org

${ }^{\dagger}$ Present address: Ngonidzashe Chirinda, Mohammed VI Polytechnic University (UM6P), AgroBioSciences (AgBS),

Agricultural Innovations and Technology Transfer Centre (AITTC),

Bengueri, Morocco

Specialty section: This article was submitted to Animal Nutrition and Metabolism, a section of the journal

Frontiers in Veterinary Science

Received: 01 July 2020 Accepted: 08 September 2020

Published: 20 October 2020

Citation:

Gaviria-Uribe X, Bolivar DM, Rosenstock TS, Molina-Botero IC Chirinda N, Barahona R and Arango J (2020) Nutritional Quality, Voluntary Intake and Enteric Methane Emissions of Diets Based on Novel Cayman Grass and lts Associations With Two

Leucaena Shrub Legumes.

Front. Vet. Sci. 7:579189. doi: 10.3389/fvets.2020.579189

\section{Nutritional Quality, Voluntary Intake and Enteric Methane Emissions of Diets Based on Novel Cayman Grass and Its Associations With Two Leucaena Shrub Legumes}

\author{
Xiomara Gaviria-Uribe ${ }^{1,2}$, Diana M. Bolivar ${ }^{1}$, Todd S. Rosenstock ${ }^{3,4}$, \\ Isabel Cristina Molina-Botero ${ }^{2}$, Ngonidzashe Chirinda ${ }^{2+}$, Rolando Barahona ${ }^{1}$ and \\ Jacobo Arango ${ }^{2 *}$
}

${ }^{1}$ Grupo de Investigación BIOGEM, Departamento de Producción Animal, Facultad de Ciencias Agrarias, Universidad Nacional de Colombia, Medellín, Colombia, ${ }^{2}$ International Center for Tropical Agriculture (CIAT), Cali, Colombia,

${ }^{3}$ World Agroforestry Centre (ICRAF), Kinshasa, Democratic Republic of Congo, ${ }^{4}$ Consortium of International Agricultural Research Centers (CGIAR) Research Program on Climate Change, Agriculture and Food Security, Kinshasa, Democratic Republic of Congo

Methane $\left(\mathrm{CH}_{4}\right)$ emissions from enteric fermentation in cattle are an important source of greenhouse gases, accounting for about $40 \%$ of all agricultural emissions. Diet quality plays a fundamental role in determining the magnitude of $\mathrm{CH}_{4}$ emissions. Specifically, the inclusion of feeds with high digestibility and nutritional value have been reported to be a viable option for reducing $\mathrm{CH}_{4}$ emissions and, simultaneously, increase animal productivity. The present study aimed to evaluate the effect of the nutritional composition and voluntary intake of diets based on tropical forages upon $\mathrm{CH}_{4}$ emissions from zebu steers. Five treatments (diets) were evaluated: Cay1: Urochloa hybrid cv. Cayman (harvested after 65 days of regrowth: low quality); Cay2: cv. Cayman harvested after 45 days of regrowth; CayLl: cv. Cayman + Leucaena leucocephala; CayLd: cv. Cayman + Leucaena diversifolia; Hay: Dichantium aristatum hay as a comparator of common naturalized pasture. For each diet representing different levels of intensification (naturalized pasture, improved pasture, and silvopastoral systems), $\mathrm{CH}_{4}$ emissions were measured using the polytunnel technique with four zebu steers housed in individual chambers. The $\mathrm{CH}_{4}$ accumulated was monitored using an infrared multigas analyzer, and the voluntary forage intake of each animal was calculated. Dry matter intake (DMI, $\%$ of body weight) ranged between 0.77 and 2.94 among diets offered. Emissions of $\mathrm{CH}_{4}$ per $\mathrm{kg}$ of DMl were significantly higher $(P<0.0001)$ in Cay1 $(60.4 \mathrm{~g})$, compared to other treatments. Diets that included Leucaena forage legumes had generally higher crude protein contents and higher DMI. Cay1 and Hay which had low protein content and digestibility had a higher $\mathrm{CH}_{4}$ emission intensity (per unit live weight gain) compared to Cay2, CayLI and CayLd. Our results suggest that grass consumed after a regrowth period of 45 days results in lower $\mathrm{CH}_{4}$ emissions intensities compared to those observed following a regrowth period of 65 days. Diets with Leucaena inclusion showed 
advantages in nutrient intake that are reflected in greater live weight gains of cattle. Consequently, the intensity of the emissions generated in the legume-based systems were lower suggesting that they are a good option for achieving the emission reduction goals of sustainable tropical cattle production.

Keywords: climate change mitigation, forage diversification, greenhouse gases, livestock, urochloa hybrid pastures

\section{INTRODUCTION}

The methane $\left(\mathrm{CH}_{4}\right)$ emissions from the livestock sector accounted for about $97 \mathrm{Mt}$ in 2014, corresponding to $\sim 2.7 \mathrm{Gt}$ of equivalent $\mathrm{CO}_{2}$ (1). The primary source of $\mathrm{CH}_{4}$ emissions in agriculture is enteric fermentation, the process in which the anaerobic digestion of feed in cattle rumen produces $\mathrm{CH}_{4}$ through the activity of methanogenic microorganisms, accounting for $44 \%$ of total emissions from this activity (2).

Early estimations of daily $\mathrm{CH}_{4}$ emissions in animals ranged from 250-500 L per animal (3). These emissions have not only environmental but also productivity implications since energy losses in the form of $\mathrm{CH}_{4}$ vary between $2-15 \%$ of total gross energy (GE) ingested (4). Although $\mathrm{CH}_{4}$ has a warming potential 21 times $>\mathrm{CO}_{2}$, its net contribution may be even higher as a greenhouse gas (GHG). However, $\mathrm{CH}_{4}$ has a short atmospheric lifetime (10-12 years compared to other greenhouse gases, i.e., 120 years for $\mathrm{CO}_{2}, 114$ years for $\mathrm{N}_{2} \mathrm{O}$ ), so reducing its emission may have short-term benefits (5) and rapid cooling effect in the atmosphere.

The way the animals are fed and the composition of the feed are crucial drivers of $\mathrm{CH}_{4}$ production due to enteric fermentation. Major determinants of the amount of enteric $\mathrm{CH}_{4}$ produced by cattle are the type, quality, and quantity of consumed forage $(6,7)$. The quality of the consumed forage is based on its carbohydrates, fat, protein, and mineral composition. The digestibility of the forage depends on the form of carbohydrates. Specifically, forages with high amounts of free sugars and starch are easier to digest, generally have shorter retention times in the rumen and, consequently, are associated with lower $\mathrm{CH}_{4}$ production compared to forages with high amounts of structural carbohydrates such as neutral detergent fiber (NDF) and acid detergent fiber (ADF) (8). Forages with high amounts of structural carbohydrates, which increase with sward age, are considered to have lower quality $(9,10)$. Several previous studies have reported lower enteric $\mathrm{CH}_{4}$ emissions with younger compared to older forage swards and attributed this difference to the higher amounts of free sugars and starch in younger forage $(10,11)$.

In tropical countries, forages are the most economical and practical feed option for cattle, which alongside with proper management, can be available throughout the year and supply adequate nutrition. However, forage nutritional quality is highly variable, and influenced by many factors such as season, age and fertilization (12). Previous studies have reported that high fiber and lignin contents reduce the level of forage voluntary intake of grazing cattle $(13,14)$. In the lower tropical regions of Colombia it has been reported that the inclusion of legumes such as Leucaena sp. is beneficial for increasing cattle productivity as it increases the supply of highly digestible protein (15), reduces the amount of structural carbohydrates and contributes toward increasing the dry matter intake (DMI) and reducing the intensity of $\mathrm{CH}_{4}$ emissions per unit DMI and dry matter digested (DMD) $(16,17)$. Cayman hybrids have been widely adopted by farmers in the Colombian lower tropics because of their tolerance to waterlogging, high forage production and contents of protein (18). However, GHG emissions associated with Cayman hybrids remain largely unknown.

The transition toward the sustainable intensification of cattle production systems may require the promotion and adoption of improved forages (i.e., inclusion of legumes and genetically improved grasses) (19-21). To contribute to sustainable cattle production these improved forages should be associated with an increase in milk and meat productivity and a reduction in GHG emissions and other harmful activities to the environment (e.g., deforestation, soil degradation, and biodiversity loss). Tropical livestock systems based on diverse, well-managed improved forages (including Leucaena) could contribute to reduce the emissions of $\mathrm{CH}_{4}(17)$, nitrous oxide $\left[\mathrm{N}_{2} \mathrm{O},(22)\right]$ and increase carbon accumulation in aerial biomass and soils (23).

While the reduction of enteric $\mathrm{CH}_{4}$ emissions is technically possible, there are still various challenges (e.g., weak policies, financial incentives, and technical assistance) that should be overcome before these technologies can be implemented at a broader scale (21). Once these hurdles are overcome, some of these forage-based technologies could effectively contribute to produce more milk and meat per unit of area and, concurrently, deliver ecosystem services such as climate change mitigation (20). Reducing the high GHG emissions associated with the cattle sector represents an opportunity for countries to advance toward achieving their Nationally Determined Contributions (NDCs) under the Paris Agreement.

We hypothesized that cattle consuming high quality forages have high voluntary intake and low $\mathrm{CH}_{4}$ emissions intensities. We also hypothesized that the inclusion of Leucaena contributes to improve the quality of the consumed diet and reduces $\mathrm{CH}_{4}$ emissions. The present study aims at generating critical technical information on forage quality, voluntary intake, optimal grazing management, and enteric $\mathrm{CH}_{4}$ emissions of a recently bred tropical forage-grass (Cayman hybrid), alone and in combination with two legume tree species (Leucaena sp.). These diets were chosen because they allowed us to test our hypothesis using forage options common in the lower tropical regions of Colombia, Cayman hybrid, Leucaena leucocephala and Leucaena 
diversifolia. We also included Dichanthium aristatum which is commonly used for hay during dry periods.

\section{MATERIALS AND METHODS}

\section{Study Site}

The experiments were conducted in the regional office for Colombia of the Alliance of Bioversity International and the International Center for Tropical Agriculture (CIAT) located in Palmira, Valle del Cauca, Colombia ( $\left.3^{\circ} 30^{\prime} 7^{\prime \prime} \mathrm{N} ; 7^{\circ} 21^{\prime} 22^{\prime \prime} \mathrm{W}\right)$ at 1,050 masl. This site has an annual mean temperature of $27^{\circ} \mathrm{C}$ and rainfall of $1008 \mathrm{~mm}$.

\section{Diets and Forage Materials}

The forages evaluated in this study were from different experimental plots located at CIAT. The soil of these plots was characterized as Cumulic Haplustoll (Soil Taxonomy, USDA 2014 ) with a silty clay texture (50 \% clay in the upper $20 \mathrm{~cm}$ soil layer) and $\mathrm{pH}=7.5$ (24).

Five treatments (diets) were evaluated in the present study: Cay1: Urochloa hybrid cv. Cayman (harvested after 65 days of regrowth); Cay2: cv. Cayman (harvested at 45 days); Cayll: cv. Cayman + Leucaena leucocephala; CayLd: cv. Cayman + Leucaena diversifolia and Hay: Hay of Dichantium aristatum used for comparison as one of the most common feed resources in the region.

In Cay1 and Cay2, animals received Urochloa hybrid cv. Cayman-CIAT BR02/1752 (Cayman) of contrasting chemical composition and nutritional quality due to differences in harvesting time (i.e., regrowth age of 65 days and 45 days for Cay1 and Cay2, respectively), to simulate two different grazing regimes. Leaves of Leucaena leucocephala CIAT 17263 and Leucaena diversifolia ILRI 15551 were hand-collected after 58 days of regrowth simulating cattle browsing. Dichantium aristatum was collected at 52 days of regrowth.

\section{Nutritional Quality of Forage-Based Diets}

Forages consumed by the cattle (four zebu steers) were analyzed at CIAT's Forage Quality and Animal Nutrition Laboratory [certified by the FAO-IAG proficiency test of feed constituents 2016 and 2017 (25)], to determine their chemical composition and nutritional value. Plant samples were dried at $55^{\circ} \mathrm{C}$ for $72 \mathrm{~h}$, following the method 6496 of the International Organization for Standardization (26) to determine the content of dry matter $(\mathrm{DM})$; and crude protein $[\mathrm{CP}=\mathrm{N}$ concentration $\times 6.25$; Kjeldahl AN 3001 FOSS; AOAC (27): method 984.14]; neutral detergent fiber (NDF) and acid detergent fiber (ADF) by the methodologies proposed by Van Soest et al. (28) adapted to an Ankom Fiber Analyzer AN 3805 (Ankom ${ }^{\circledR}$ Technology Corp. USA); gross calorific value using calorimetry was determined per [ISO 9831, (29)] specifications and in vitro DMD by the technique of Tilley and Terry (30). Condensed tannins (CT) were determined only for the treatments containing Leucaena, according to the method described by Terrill et al. (31).

\section{Experimental Design and Animals Management}

Four zebu steers with an initial weight of $220 \pm 18 \mathrm{~kg}$ were used in the evaluation of all treatments, which finalized in July 2017. One diet (out of five) was provided to the four animals for 19 days, of which the first 15 days were for adaptation to the diet, in which the animals grazed the experimental plots ad libitum. Following the adaptation period to the diet, the animals were moved to the polytunnel for 3 days for acclimatization to the polytunnel conditions. During these 3 days, the steers were subjected to short periods of total polytunnel enclosure during the day. Measurements of $\mathrm{CH}_{4}$ emissions were made in closed polytunnels with the individual animals on day 19 of the experimental period. This methodology was used to assess each diet described in section Diets and Forage Materials.

\section{Polytunnel Conditions}

Measurements of $\mathrm{CH}_{4}$ were conducted as described by Lockyer (32) and Murray et al. (33). Two polytunnels (Area: $48 \mathrm{~m}^{2}$ and volume: $134 \mathrm{~m}^{3}$ ) were used; each of these structures had an entrance for two animals. On the opposite side, there was a 12" fume extractor set at an extraction rate of $0.9 \mathrm{~m}^{3} \mathrm{~s}^{-1}$ to allow the collection of gas samples. Each polytunnel was sub-divided into two independent chambers, each with a volume of $67 \mathrm{~m}^{3}$, making it possible to evaluate four independent animals simultaneously. Gas samples were collected every 60 to $90 \mathrm{~min}$ from inside and outside each polytunnel chamber over $24 \mathrm{~h}$, starting at 08:00 am, accounting for 18 different sampling times. At the end of each measurement, the polytunnel was opened to release accumulated gas before beginning new gas measurements.

The environmental conditions inside and outside (environmental) the polytunnel were monitored continuously during the experimental period to ensure that the temperature and humidity inside the tunnel did not generate heat stress in the animals. In addition, a solar screenwas installed to provide shade for the polytunnel and prevent high temperatures inside the polytunnel, which would affect the animals' welfare during the hottest hours of the day.

\section{Methane Concentration in Gas Samples}

Every measurement consisted of the collection of gas samples every $20 \mathrm{~s}$ using a portable FTIR gas analyzer Gasmet DX4040 (Gasmet Technologies Oy ${ }^{\circledR}$, Helsinki, Finland). The equipment was calibrated with ultrapure dinitrogen gas grade 5.0 according to manufacturer instructions.

The amount of $\mathrm{CH}_{4}$ was calculated using the ideal gas law (34), from the concentration (ppm) reported by the Gasmet ${ }^{\circledR}$ and the total volume of the polytunnel. Additionally, ambient air was sampled each time the sample was taken from inside the tunnel, in order to correct each gas measurement obtained.

\section{Dry Matter Intake}

Forages of the different diets were offered individually to animals in feeders installed inside the polytunnels. These forages were cut directly from the experimental grazing plots and offered fresh without being chopped (Hay was the only treatment that was offered dry). The harvesting of the forages was done to simulate 
the intake behavior observed when the animals were grazing. All animals had ad libitum access to forages, salt, and water throughout the experimental period. No additional concentrates or supplements were added. The voluntary daily intake of each individual animal, for each of the diets was calculated as the difference between the amount of forage offered and rejected.

\section{Expected Live Weight Gains}

Body weight (BW) gains ( $\mathrm{g}$ per day) were estimated using The Cornell Net Protein and Carbohydrate System-CNCPS ${ }^{\circledR}$ version 6.0 (35). Input variables for the model included animal management, environmental variables, chemical forage composition, initial animal body weight, and DMI.

\section{Data Analyses}

Data were analyzed using the GLM procedure of the software Statistical Analysis Systems ${ }^{\circledR}$, version 9.2 (36). The experimental design was a randomized complete block design with the animal considered as the block. The animal weight was used as a covariate, to eliminate errors associated with changes in animal weight over time. Multiple comparisons were evaluated using Tukey's HSD test. Relationships between $\mathrm{CH}_{4}$ emitted, and DMD or NDF- ADF intake and DMI and nutrient content were analyzed by type II linear regression using PROC REC procedure of SAS.

\section{RESULTS}

\section{Nutritional Quality and Digestibility of Forage-Based Diets}

The evaluated diets showed differences in the contents of nutrients and digestibility (Table 1). Treatments including Leucaena (CayLl and CayLd) had two to three times higher CP compared to grass-alone treatments, whereas the late-harvested Cayman grass Cayl showed the lowest CP among all diets. Contents of NDF and ADF tended to decrease in the treatments in which the Cayman grass was combined with Leucaena forages (CayLl and CayLd). Ash content varied between 118 and $175 \mathrm{~g}$ $\mathrm{kg} \mathrm{DM}^{-1}$ for the evaluated diets, while GE intake was, on average, 16.9 MJ kg DM${ }^{-1}$ for all diets except for the control diet (Hay, 14.1 MJ kg DM ${ }^{-1}$ ). The digestibility of the diets ranged from 479-618 $\mathrm{g} \mathrm{kg} \mathrm{DM}^{-1}$, with Cayl and the Hay being the least digestible treatments. Treatments of the same grass (Cayman) that differed in harvesting times showed dissimilar CP contents and digestibility. Cay 2 had $46.5 \%$ more CP content and $17.3 \%$ more digestibility than Cayl (Table 1). The contents of CT were 28.8 and $32.6 \mathrm{~g} \mathrm{~kg} \mathrm{DM}^{-1}$ for L. leucocephala and L. diversifolia, respectively.

\section{Dry Matter and Nutrient Intake}

The consumption of each plant fraction in the mixed diets was similar for both treatments. For the CayLl diet, animals consumed $77.5 \%$ grass and $22.5 \%$ legume, whereas, in CayLd, the animals consumed $81.8 \%$ grass and $18.2 \%$ legume. DMI was highest in diets that included the Leucaena forages (CayLl and CayLd), reaching values up to $2.94 \%$ of BW $(P<0.001)$, whereas the lowest DMI corresponded to the treatments of
TABLE 1 | The nutritional value of five different diets based on tropical-forages (treatments) evaluated offered to Brahman cattle steers.

\begin{tabular}{|c|c|c|c|c|c|}
\hline & Cay1 & Cay2 & CayLI* & CayLd** & Hay \\
\hline $\mathrm{DM}$ & 391 & 213 & 211 & 238 & 632 \\
\hline $\mathrm{CP}, \mathrm{g} \mathrm{kg} \mathrm{DM}{ }^{-1}$ & 44.5 & 83.3 & 96.2 & 128.5 & 62.3 \\
\hline $\mathrm{NDF}, \mathrm{g} \mathrm{kg} \mathrm{DM}{ }^{-1}$ & 709.8 & 682.2 & 638.5 & 580.9 & 612.6 \\
\hline ADF, $\mathrm{g} \mathrm{kg} \mathrm{DM}^{-1}$ & 414.2 & 349.1 & 359.2 & 299.3 & 388.9 \\
\hline Ash, $\mathrm{g} \mathrm{kg} \mathrm{DM}^{-1}$ & 118.3 & 121.4 & 124.5 & 175.6 & 140.3 \\
\hline $\mathrm{GE}, \mathrm{Mj} \mathrm{kg} \mathrm{DM}^{-1}$ & 16.2 & 17.2 & 16.7 & 17.5 & 14.1 \\
\hline IVDMD, $\mathrm{g} \mathrm{kg}^{-1}$ & 511 & 618 & 610 & 606 & 479 \\
\hline
\end{tabular}

${ }^{*}$ Content of condensed tannins of Leucaena leucocephala $=28.8 \mathrm{~g} / \mathrm{kg} \mathrm{DM}$; * Content of condensed tannins of Leucaena diversifolia $=32.6 \mathrm{~g} / \mathrm{kg} D M$.

DM, Dry matter; $C P$, crude protein; NDF, neutral detergent fiber; $A D F$, acid detergent fiber; GE, gross energy; IVDMD, in vitro dry matter digestibility. Cay1 and Cay2 diets correspond to Urochloa hybrid cv. Cayman-CIAT BR02/1752 (Cayman) collected at different times of regrowth (i.e., 65 and 45 days, respectively). CayLI is a mixture of Cay2 and Leucaena leucocephala CIAT 17263; CayLd is a mixture of Cay2 and Leucaena diversifolia ILRI 15551. Hay is dried material of Dichantium aristatum.

lower nutritional quality (Cayl and Hay) (Table 2). The highest differences in nutrient intake were related to CP content. The treatments that included legumes provided an average of four times more $\mathrm{CP}$ than grass alone treatments $(P<0.001)$.

\section{Methane Emissions}

The total $\mathrm{CH}_{4}$ accumulated during the 24-h measurement period ranged between $74.7 \mathrm{~g}$ and $164.2 \mathrm{~g}$ animal $^{-1}$ and was statistically higher $(P<0.0001)$ in treatments CayLl and CayLd that included the legumes (Figure 1). No significant differences were observed among the other grass alone treatments. Methane accumulated per hour varied between 4.4 and $10.2 \mathrm{~g}$. When $\mathrm{CH}_{4}$ emissions were expressed per $\mathrm{kg}$ of $\mathrm{DMI}, \mathrm{kg}$ of $\mathrm{DMD}$, or organic matter digested (OMD), there was an opposite relationship to that obtained when $\mathrm{CH}_{4}$ emissions were expressed as $\mathrm{g} \mathrm{CH}_{4}$ animal ${ }^{-1}$ day $^{-1}$ (See Figure 1 and Table 3). The diets that had higher total emissions as $\mathrm{g} \mathrm{CH}_{4}$ animal $^{-1} \mathrm{day}^{-1}$ (CayLl and CayLd) had the lowest emissions of $\mathrm{CH}_{4}$ per $\mathrm{kg}$ of DMI, $\mathrm{kg}$ DMD or OMD, and consequently, these were the treatments with the lower energy losses as a percent of GE intake (Ym).

A strong positive relationship was observed between $\mathrm{CH}_{4}$ emissions and parameters like DMD (Figure 2A), NDF intake (Figure 2B), and ADF intake (Figure 2C). These relations resulted in calculations of $\mathrm{CH}_{4}$ emissions increasing $29.7 \mathrm{~g} \mathrm{CH}_{4}$ animal $^{-1}$ day $^{-1}$ per each additional $\mathrm{kg}$ of DMD, $31.9 \mathrm{~g} \mathrm{CH}_{4}$ animal $^{-1}$ day $^{-1}$ per each additional kg of NDF consumed, and $61.3 \mathrm{~g} \mathrm{CH}_{4}$ animal $^{-1}$ day $^{-1}$ per each additional $\mathrm{kg}$ of $\mathrm{ADF}$ consumed. Furthermore, a strong positive relationship was found between DMI and the content of CP in the diet (Figure 3A); and a negative relationship was observed between DMI and fiber content in the five diets evaluated (Figure 3B). Precisely, the DMI increased by $78 \mathrm{~g}$ when the CP increased by $1 \mathrm{~g} \mathrm{~kg}^{-1}$ $\mathrm{DM}$ but decreased by $53 \mathrm{~g}$ for each $\mathrm{kg}$ of $\mathrm{ADF}$ contained in the diets evaluated.

During the experimental period, maximum internal temperatures recorded in the polytunnel ranged between 
TABLE 2 | Average dry matter and nutrient intake in zebu steers fed with tropical forages of different composition and nutritional value.

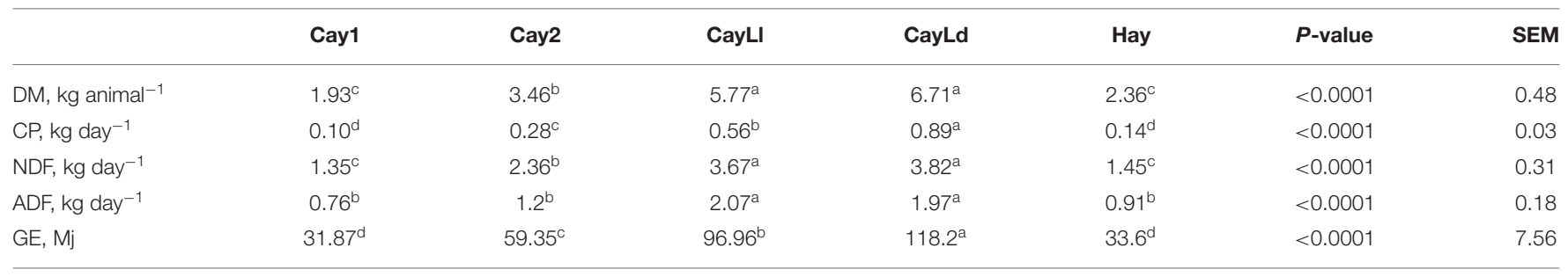

$a, b, c, d$, mean values among the same row with different superscript are significantly different ( $P<0.05)$; $S E M$, Standard error of the mean; BW, body weight; DM, dry matter; $C P$, crude protein; NDF, neutral detergent fiber; ADF, acid detergent fiber; GE, gross energy. Cay1 and Cay2 diets correspond to Urochloa hybrid cv. Cayman-CIAT BR02/1752 (Cayman) collected at a different time of regrowth (i.e., 65 and 45 days, respectively). CayLI is a mixture of Cay2 and Leucaena leucocephala CIAT 17263; CayLd is a mixture of Cay2 and Leucaena diversifolia ILRI 15551. Hay is the dried material of Dichantium aristatum.

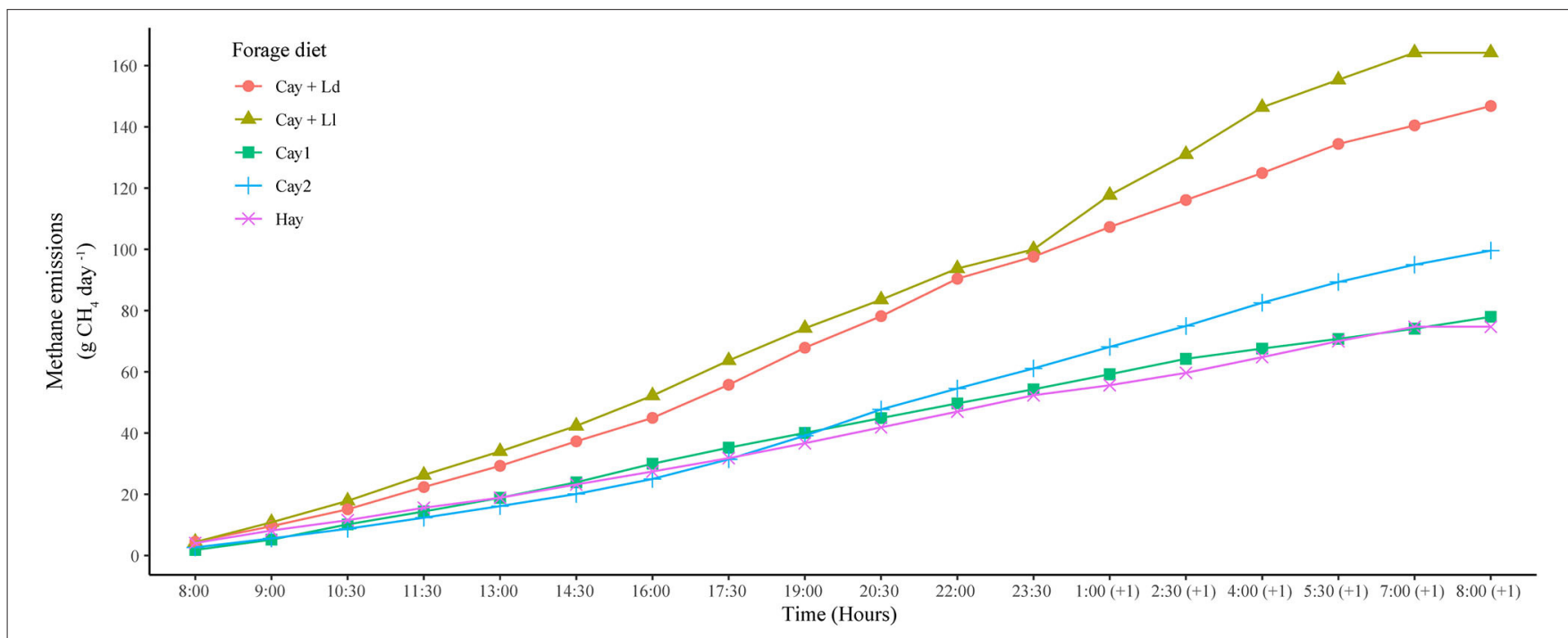

FIGURE 1 | Accumulated methane emissions in zebu steers fed with tropical forages of different nutritional value.

TABLE 3 | Daily production of methane in zebu steers fed with tropical forages of different composition and nutritional value.

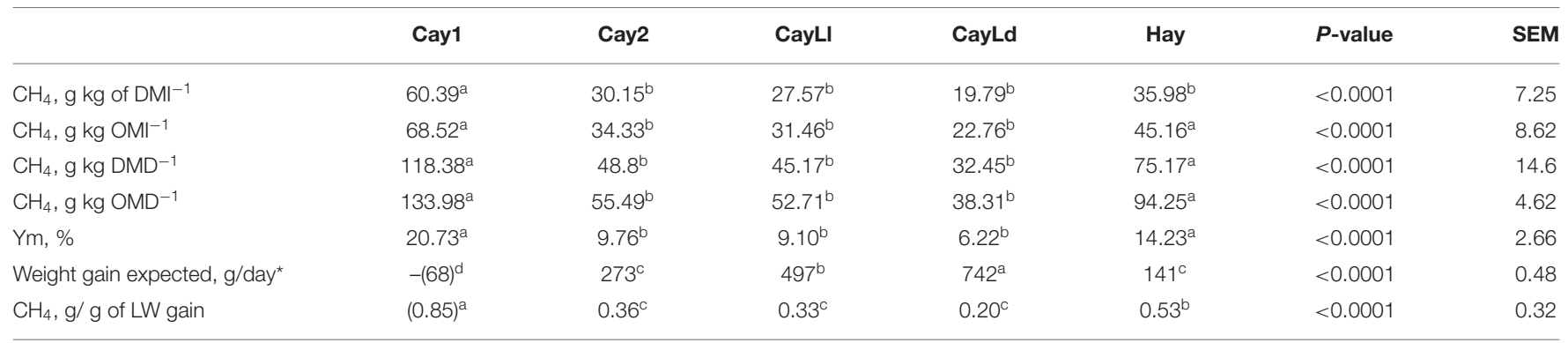

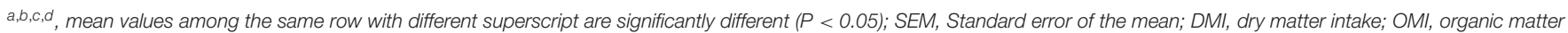

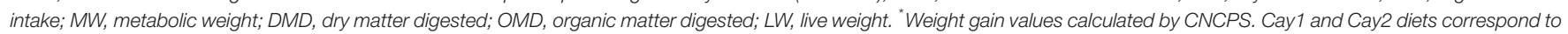

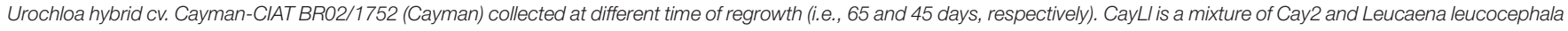
CIAT 17263; CayLd is a mixture of Cay2 and Leucaena diversifolia ILRI 15551. Hay is dried material of Dichantium aristatum.

$30-32.6^{\circ} \mathrm{C}$ and were reached at around $14: 00$ and $15: 30 \mathrm{~h}$. Minimum internal polytunnel temperatures ranged from 17$22.3^{\circ} \mathrm{C}$ and were recorded between 4:00-6:00 h. Whereas, the ambient temperatures were generally lower than those recorded in the polytunnel the differences did not exceed $1.5^{\circ} \mathrm{C}$. Relative humidity $(\mathrm{RH})$ values were always higher inside compared to outside the polytunnel. When the highest $\mathrm{RH}(\sim 92 \%)$ were recorded inside the polytunnel, between 2:00 and 5:00 h, the outside $\mathrm{RH}$ values were $\sim 84 \%$.

\section{Expected Live Weight Gains}

Expected live weight gains for animals in different treatments are shown in Table 3. Animals that consumed Cayl were expected to lose weight, while for the other treatments, the weight gain 
A

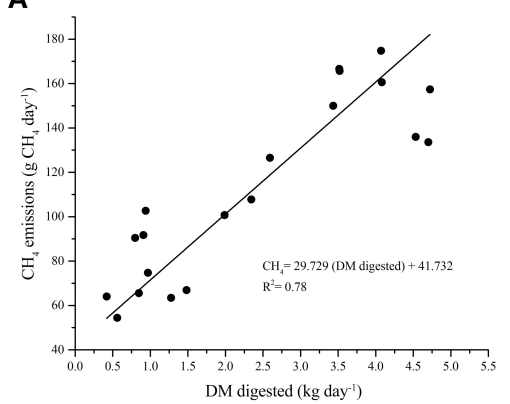

B

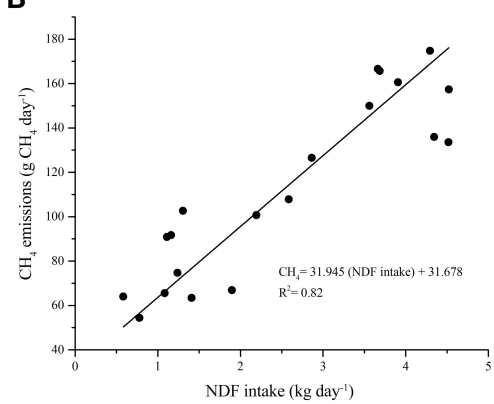

C

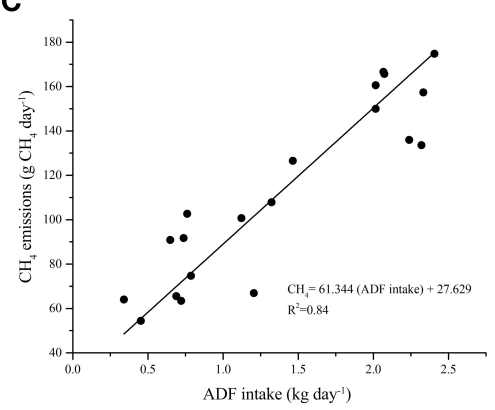

FIGURE 2 | (A) Relationship between dry matter digested ( $\mathrm{kg}$ animal day ${ }^{-1}$ ) and enteric methane emissions ( $\mathrm{g}$ day $\left.{ }^{-1}\right)$. (B) Relationship between NDF intake ( $\mathrm{g}$ kg $\left.\mathrm{DM}^{-1}\right)$ and enteric methane emissions $\left(\mathrm{g}\right.$ day $\left.{ }^{-1}\right)$. (C) Relationship between ADF intake $\left(\mathrm{g} \mathrm{kg} \mathrm{DM}^{-1}\right)$ and enteric methane emissions $\left(g\right.$ day $\left.{ }^{-1}\right)$.

A

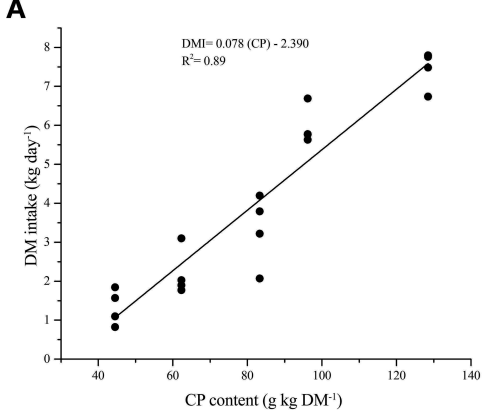

B

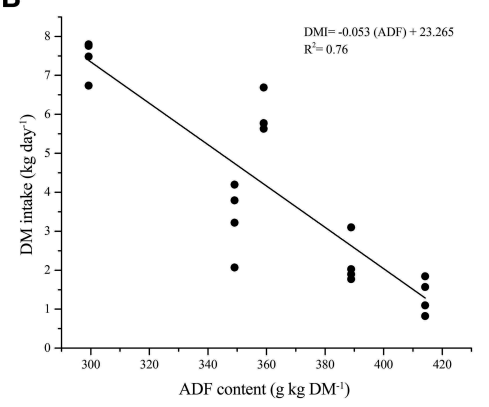

C

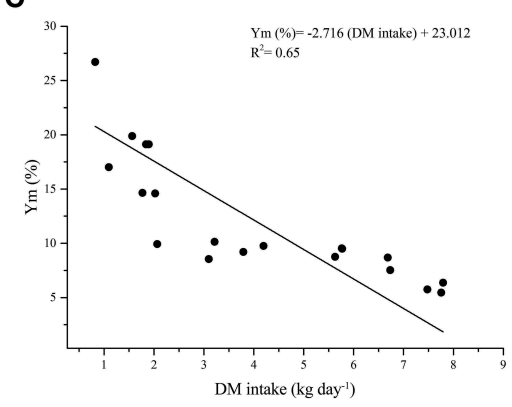

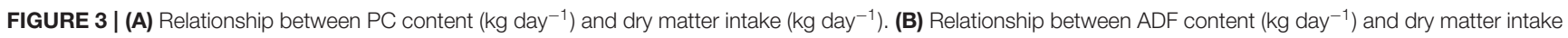
$\left(\mathrm{kg}\right.$ day $\left.^{-1}\right)$. (C) Relationship between $\mathrm{Ym}(\%)$ and dry matter intake $\left(\mathrm{kg} \mathrm{day}^{-1}\right)$.

ranged between 141 and $742 \mathrm{~g} \mathrm{day}^{-1}$ for the Hay and CayLd diets, respectively. The amounts of $\mathrm{CH}_{4}$ emitted by animals that consumed Cayl diet in relation to their live weight gain was calculated assuming that the animals transition from consuming this forage to consuming the Cay2 treatment forage which is of better nutritional quality. In this way the animals move from losing $68 \mathrm{~g} \mathrm{day}^{-1}$ to gaining $205 \mathrm{~g} \mathrm{day}^{-1}$.

\section{DISCUSSION}

\section{Nutritional Quality of Forage Based-Diets}

Our results showed that an improvement in the nutritional quality in diets based on tropical forages was associated with an increase in DMI, especially when legumes were included in the diet. Diets based on feeds with high fiber contents (NDF and ADF) were less digestible, while those based on feed with low fiber contents were more digestible (Table 1). This observation is because the amount of fiber present in forages is directly related to the increase in resistance to the reduction of forage particle size and, therefore, inversely related to its digestibility (12). Likewise, the rate of passage of the feed is inversely related to its fiber content: a high fiber content decreases the potential for DMI by increasing the feed retention time in the rumen $(37,38)$.

The nutritional quality of the diet is a significant factor influencing DMI and productivity. Low nitrogen and high fiber contents may limit the DMI by the animal. These two variables showed a close relationship in the present study and showed that the high CP content (Figure 3A) and the lower fiber content (Figure 3B), resulted in an improvement of DMI by the animals. It is commonly accepted that in diets with $8-10 \%$ CP (grass-alone diets), consumption is limited by the capacity of the reticulum-rumen and the rate of passage of the intake, and if the diet exceeds $10 \%$ CP (e.g., in grass-legume diets), consumption is probably affected by other metabolic factors (39).

\section{Nutrient Intake and Digestibility}

Dry matter intake is regulated by digestive and metabolic factors, such as the reticulum-rumen fill, osmolality, and kinetics, as well as specific digestive hormones and blood metabolites derived from feed digestion or catabolism (Forbes, 2000). Rumen filling is related to the fiber concentration of the feed consumed by the animal, which could explain our results regarding the decrease of DMI with the increase of the fiber concentration (Figure 3B). However, the filling effect of diet also depends on factors affecting digestion rates and fluxes of the reticulumrumen, such as particle size and density and intake of NDF (40). Since NDF intake is directly related with $\mathrm{CH}_{4}$ emissions $(41,42)$, the intake of fiber may explain the $\mathrm{CH}_{4}$ production observed in treatments with higher NDF in this current study (Figure 2B). 
It is important to highlight that the leaves of forages such as Leucaena have been reported to contain mimosine (2.3$12 \% \mathrm{DM}$ ) which, depending on their concentration, can modify ruminal fermentation and, thus, $\mathrm{CH}_{4}$ emissions $(43,44)$. An invitro study conducted in Brazil by Soltan et al. (45) reported that mimosine stimulated acetogenesis as an alternative to methanogenesis in the rumen, leading to a reduction in $\mathrm{CH}_{4}$ emissions without adverse effects on nutrient degradability. The cited study was however inconclusive on the role of mimosine in $\mathrm{CH}_{4}$ reductions (45). In the present study, the concentration of mimosine in Leucaena forage was not determined. Therefore, future research need to explore the effects of mimosine on $\mathrm{CH}_{4}$ production, ruminal fermentation parameters, nutrient consumption, and degradability.

The CT contents of the two Leucaena species did not appear to have adverse effects either on digestibility or DMI of the evaluated diets. The CT content of the two diets that included Leucaena did not exceed $50 \mathrm{~g} \mathrm{~kg} \mathrm{DM}^{-1}$, which has been reported as the threshold CT content beyond which palatability is reduced (46). Our findings corroborate with Montoya-Flores et al. (47) that reported that the inclusion of $12 \% \mathrm{~L}$. leucocephala leaves in a grass-based diet resulted in a CT contents of $0.27 \%$ which was enough to increase the digestibility of dietary protein and organic matter while reducing $\mathrm{CH}_{4}$ production, without adverse effects on the microbial populations and rumen fermentation. On the other hand, Piñeiro-Vasquez et al. (48) reported that $L$. leucocephala as a source of CT has an optimal inclusion level of $20-40 \%$ of the DM on the ration and in this range can reduce $\mathrm{CH}_{4}$ emissions and improve nitrogen intake without affecting DMI.

In the current study, offering diets with low protein content, high fiber and low digestibility led to depressions in DMI and to lower $\mathrm{CH}_{4}$ emissions per animal per day (Figures 2, 3), but higher $\mathrm{CH}_{4}$ emissions when expressed per unit DMI, DMD and OMD (Table 3). Forage intake and digestibility are some of the most important factors limiting the production of cattle grazing in tropical forages, and it has been reported that when the diets have $<6 \%$ of $\mathrm{CP}$, there are restrictions to cattle intake and productivity due to a protein deficiency $(49,50)$. Hence, it is critical to identify strategies to increase both nutrient intake and proper forage grazing. From the results of this investigation, it can be concluded that the dietary inclusion of both L. leucocephala and L. diversifolia is a suitable option to increase cattle productivity under tropical conditions.

The voluntary intake of forage and nutrients was higher for the Cayman-Leucaena diets (CayLl and CayLd), being up to $2.97 \%$ of BW (Table 2). Similar results were reported by Molina et al. (17), who observed DMI of $2.47 \%$ of BW when Leucaena was included in the diet compared to $2.02 \%$ in a grass only diet. Likewise, Cuartas et al. (16) reported a voluntary DMI of $2.60 \%$ of BW when animals were offered intensive silvopastoral systems diets consisting of $31 \%$ L. leucocephala and 69\% Megathyrsus maximus. For an intensive silvopastoral system with L. leucocephala, Gaviria-Uribe et al. (15) reported intakes of $2.46 \%$ of BW of a diet with $53.5 \%$ digestibility. These results suggest that the inclusion of legumes can be a strategy to increase DM and nutrient intake in cattle and, consequently, productivity, ameliorating a fundamental limitation of tropical cattle production, the consumption of low-quality diets that hinder a transition toward a sustainable intensification process.

There are several reports on the nutritional and productivity benefits of including L. leucocephala in the diet of grazing beef and dairy cattle (51-55). However, the current study is the first to report the benefits of including $L$. diversifolia in the diet of grazing cattle in Latin America. The two legumes used in the current study enabled us to evaluate feed options adapted to different soil conditions, altitudes and similar precipitation. In its native range, L. leucocephala grows in alkaline soils $(\mathrm{pH}$ 7.0-8.5) and altitudes up to 2,000 masl, whereas L. diversifolia grows in mildly acid soils ( $\mathrm{pH} 5.5-6.5$ ) below 1,500 masl. Only L. leucocephala tolerates long dry seasons (of up to 7 months). On the other hand, L. diversifolia is well-adapted to low temperatures at which $L$. leucocephala ceases to grow $\left(16^{\circ} \mathrm{C}\right)(56)$. In terms of nutritional quality, L. diversifolia can have CP values of $20-25 \%$ with a digestibility of $60 \%$, while L. leucocephala has CP values of between 12 and 25\% with a higher digestibility (65-85\%) (57).

\section{Methane Emissions}

It has been reported that cattle with higher consumption of organic matter are associated with a greater physiological capacity of the rumen, longer retention times, and higher digestion rates, increasing $\mathrm{CH}_{4}$ production (58, 59). Similar findings were observed in the current study, where the amount of $\mathrm{CH}_{4}$ that was emitted was related to the DMD (Figure 2A), $\mathrm{NDF}$ (Figure 2B), and ADF intake (Figure 2C). High NDF and ADF intake increased $\mathrm{CH}_{4}$ emissions and conversely, greater degradability of DM and OM resulted in lower $\mathrm{CH}_{4}$ emissions. The DMI and the composition of the diet have a major impact on enteric $\mathrm{CH}_{4}$ production, and many of the $\mathrm{CH}_{4}$ emission reduction strategies are focused on handling these two components $(60,61)$, which is aligned with our observations.

The variables of DMI, nutrient content, and $\mathrm{CH}_{4}$ emissions were strongly related to each other (Figures 2, 3). Treatments with higher nutritional quality, i.e., higher digestibility, higher CP content, and lower FDN and FDA content had higher DMI and lower $\mathrm{CH}_{4}$ emissions and, therefore, lower energy loss in the form of $\mathrm{CH}_{4}$. As a consequence, the intensity of these emissions was lower when related to animal production parameters (Table 3 ).

It is relevant to note that although Cay1 and Cay2 diets corresponded to the same grass, large differences were observed in their nutritional quality due to different harvesting times (Table 1) that aimed at stimulating two grazing management practices. These differences directly impacted the voluntary DMI (Table 2) and $\mathrm{CH}_{4}$ emissions from each of these treatments (Table 3). As expected, Cay2 had a higher nutritional quality, DMI, and resulted in lower $\mathrm{CH}_{4}$ emissions compared to Cayl, most probably due to higher lignification in Cay1. When Cay2 was compared to treatments associated with Leucaena (CayLl and CayLd), no significant differences in $\mathrm{CH}_{4}$ emissions (g of $\mathrm{CH}_{4}$ per kg of DM) were observed (Table 3). Furthermore, forage yield and their nutritional quality are influenced by numerous factors such as biotic and abiotic conditions and management practices, namely cutting (including grazing and browsing) frequency, plant maturity, climatic conditions, and soil fertility, among 
others. A longer maturation time of the grass results in lower protein content and higher fiber and lignin contents (9).

In this sense, proper grazing management of a pasture determines its nutritional quality and, therefore, the productivity parameters of the animals, including $\mathrm{CH}_{4}$ generation. Improving the quality of the fodder consumed by the animals is a feasible option to mitigate $\mathrm{CH}_{4}$ emissions, in which absolute emissions may increase, but improved animal performance decreases the intensity of emissions. However, grazing management needs constant adaptation as it is highly dependent upon weather and other environmental factors, and their adoption is limited by technical knowledge and its transfer $(60,62)$.

The Hay treatment was included as natural pastures are highly abundant in livestock systems in the tropics. Hay from natural pasture is one popular option for conserving forage for times of limited forage availability (e.g., extended drought periods). The high values of $\mathrm{CH}_{4}$ emissions in this treatment, low digestibility, and consumption by the animals were mainly related to its nutritional quality (Tables 1, 3). In general, naturalized pastures produce more $\mathrm{CH}_{4}$ emissions as influenced by DMI, degradation, and passage rates (63). However, an important factor in hay preparation and storage is to keep the material dry. If humidity is present, problems of plant material deterioration can occur, which could also affect the fodder quality and consumption by animals.

Treatments that had higher DMI had the highest $\mathrm{CH}_{4}$ emissions $\left(\mathrm{g} \mathrm{day}^{-1}\right)$ (Figure 1). However, when analyzing these emissions per unit of DMI and DMD, this relationship changed, and the treatments with higher DMI (CaLl and CaLd) showed lower emissions per unit of DMI and DMD (Table 3, Figure 2). Similar findings have been reported by various authors $(10,64)$. In addition, Montenegro et al. (65) also observed reductions in $\mathrm{CH}_{4}$ emissions of $25 \%$ (31 vs. $23 \mathrm{~g} \mathrm{CH}_{4} \mathrm{~kg} \mathrm{DMI}^{-1}$ ) when the animals consumed more DM of high-quality diets. It has been reported that $\mathrm{CH}_{4}$ emissions can increase as a result of increased DMI, but the intensity of emissions per unit product would also be reduced $(17,58,60,66)$ probably as a result of the better nutritional quality and digestibility of these diets (58, 67-69). These observations show the importance of adequately managing grazing and browsing regimes of forages as this could influence not only DMI but also $\mathrm{CH}_{4}$ emissions. In turn, improved grazing management techniques are a mitigation strategy with potential on open grazing cattle systems.

Both tree legume species presented similar CT, DMI, and DMD. However, $L$. diversifolia seems to have a greater potential for reducing $\mathrm{CH}_{4}$ emissions than L. leucocephala (Table 3). Several previous studies have reported that the factors influencing the concentrations of tannins in plants include plant genotype, tissue developmental stage, environmental conditions, plant part, soil fertility and the method of forage collection (70-73). Likewise, the effect on $\mathrm{CH}_{4}$ emissions and the nutritional effects of CT are also highly influenced by their structural characteristics, including the composition of proanthocyanidins and molecular weight (74).

Analysis of the energy losses in the form of $\mathrm{CH}_{4}$ observed in this study suggests that in the lower quality diets, this loss is much higher due to the maintenance requirements of metabolizable energy of animals, and this proportion decreases with better quality diets (Table 3). Hence, with increased diet quality, more energy will be available for productive processes, effectively reducing the intensity of $\mathrm{CH}_{4}$ emissions. The "Methane conversion factor," also known as "methane yield" $\left(\mathrm{Y}_{\mathrm{m}}\right)$, considers the $\mathrm{CH}_{4}$ emitted per unit of feed energy intake when both variables are expressed as the energy of combustion (75). When fed with grass of better nutritional quality (Cay2), animals had improved efficiency in the utilization of feed and, therefore, lower energy loss in the form of $\mathrm{CH}_{4}$, as suggested by Blaxter and Clapperton (76).

Methane yield values obtained for most treatments exceed the value suggested by the (77) (7.2\%) (78), but some are similar to those reported by other authors for cattle fed in tropical countries. For example, (67) reported $\mathrm{Y}_{\mathrm{m}}$ values ranging between $6.7 \%$ and $11.4 \%$ in mature Brahman cattle fed with diets based on tropical forages and (17) reported $\mathrm{Y}_{\mathrm{m}}$ values of 7.96 in cattle consuming a 74\% Cynodon plectostachyus and $26 \%$ L. leucocephala diet, and of 9.42 when receiving a $100 \% C$. plectostachyus diet. Also, Molina-Botero et al. (79) reported that heifers supplemented with Gliricidia sepium foliage mixed with ground pods of Enterolobium cyclocarpum presented less GE loss in the form of $\mathrm{CH}_{4}\left(\mathrm{Y}_{\mathrm{m}}=7.59 \%\right)$ than those fed with grassalone $\left(\mathrm{Y}_{\mathrm{m}}\right.$ above $\left.8.1 \%\right)$. In those reports and the present study, it seems improving the quality of the diets offered, resulted in more efficient use of consumed energy, which results in lower $\mathrm{Y}_{\mathrm{m}}$ values. Increasing forage intake improves feed conversion efficiency because $\mathrm{CH}_{4}$ losses, as a proportion of the energy consumed are reduced $(50,67)$. The energy use efficiency of diets can also be observed from the relationship between $\mathrm{Y}_{\mathrm{m}}$ and DMI $\left(\mathrm{kg} \mathrm{d}^{-1}\right)$. In this study, superior energy losses as a percentage of GE in the form of $\mathrm{CH}_{4}$ occurred when DMI decreased (Table 3 ).

Other authors have reported similar results to those observed in this study, in which the proportion of $\mathrm{Y}_{\mathrm{m}}$ increases in diets high in fiber (80-82). It is essential to consider that in this study, there was very low DMI as a result of offering a very lowquality grass in Cayl (low-quality Urochloa hybrid cv. Cayman). The very low-quality grasses are generally not typically used for experimentation. For this reason, the exceptionally high $\mathrm{Y}_{\mathrm{m}}$ values obtained with the low-quality Cayman grass, although not unexpected, are difficult to compare to other reports.

\section{Expected Live Weight Gains}

According to the expected live weight gains with the different treatments, animals with such a low level of DMI and nutritional value observed in Cayl are expected to lose weight. However, in a real situation, the animals would not lose weight for the rest of their productive stage. In general, cattle fed with tropical pastures present a lower live weight gain than cattle fed with temperate pastures. Nevertheless, growth stages are different in the animal's life, and live weight could be more evident in some of them (83).

There was a clear significant difference in the expected live weight gain and a significant difference in $\mathrm{CH}_{4}$ emissions between treatments with $L$. leucocephala and $L$. diversifolia. Treatments like Cay2 and CayLl did not significantly differ in the amount of $\mathrm{CH}_{4}$ emitted ( $\mathrm{g}$ g of live weight gain ${ }^{-1}$ ), however, expected weight gain was higher in CayLl, so the emissions 
intensity was lower for this treatment. A study conducted in Australia reported that the introduction of legumes generally resulted in an annual live weight increase of $60 \mathrm{~kg}$ (83). Also, Leucaena trees which seem to improve nutritional value and add nitrogen to the soil, improve grazing resistance and longevity (84), can be used in intensive rotational grazing systems (52) and are reported to be the most cost-effective option for a finishing period at the end of the growth path (85).

\section{Perspectives}

Colombia has the ambition of reducing the economy-wide GHG emissions by $20 \%$ (86). As a major GHG emitter, the cattle sector is called to cut emissions in order to achieve these targets. As suggested by our findings, there is an important variation in $\mathrm{CH}_{4}$ emissions associated with cattle feed options. To account for this variation in national GHG inventories, there is a need to move to higher Tier emission estimation methods (Tier 2 to Tier 3) with the IPCC guidelines. Results from the current study indicate that grazing management that accounts for the age of the pasture could be a viable GHG mitigation option. However, while in our study the inclusion of Leucaena sp. did not result in significant reductions of total $\mathrm{CH}_{4}$ emissions, farmers could benefit from higher live weight gains compared to grass alone pastures. This efficiency improvement indicates a reduction in $\mathrm{CH}_{4}$ emission intensities $\left(\mathrm{kg}\right.$ of $\mathrm{CH}_{4}$ per $\mathrm{kg}$ of meat). Additionally, and based on our experimental data, farmers can benefit from superior live weight gain rates by adopting L. diversifolia over L. leucocephala.

\section{CONCLUSIONS}

The nutritional quality of the diet offered to the cattle directly influences the voluntary intake and $\mathrm{CH}_{4}$ emissions generated. In the present study, the diets with the highest dry matter intake were those where Leucaena was included. Likewise, cattle fed with grass harvested at 45 days of regrowth resulted in a lower energy loss as methane and higher dry matter intake compared to cattle fed with grass harvested at 65 days of regrowth. Also, although $\mathrm{CH}_{4}$ emissions from an adequately managed pasture were similar to those emitted from diets that include Leucaena, the legume-based systems offer additional advantages in DM that are reflected in the higher live weight gains of cattle, so the intensity of the $\mathrm{CH}_{4}$ emissions generated in legumebased system were lower and making these systems a good

\section{REFERENCES}

1. Dangal SR, Tian H, Zhang B, Pan S, Lu C, Yang J. Methane emission from global livestock sector during 1890-2014: magnitude, trends and spatiotemporal patterns. Global Change Biol. (2017) 234:4147-61. doi: 10.1111/gcb.13709

2. GLEAM. Global Livestock Environmental Assessment Model - GLEAM. (2019) Available online at: http://www.fao.org/gleam/en/ (accessed September 2019).

3. Johnson K, Johnson DE. Methane emissions from cattle. J Anim Sci. (1995) 73:2483-92. doi: 10.2527/1995.7382483x

4. Giger-Reverdin S, Sauvant D. Methane production in sheep in relation to concentrate feed composition from bibliographic data. In: Ledin I, option to implement for transitioning toward sustainable tropical cattle production.

\section{DATA AVAILABILITY STATEMENT}

The raw data supporting the conclusions of this article will be made available by the authors, without undue reservation.

\section{ETHICS STATEMENT}

The animal study was reviewed and approved by Ethics Committee of the International Center for Tropical Agriculture (CIAT) and following protocols of the Colombian law No. 84/1989.

\section{AUTHOR CONTRIBUTIONS}

XG-U, DB, TR, NC, RB, and JA: conceptualization and methodology. XG-U, DB, and RB: formal analysis. XG-U: writing - original draft preparation. XG-U, DB, TR, IM-B, $\mathrm{NC}, \mathrm{RB}$, and JA: writing - review \& editing. $\mathrm{DB}, \mathrm{RB}$, and JA: supervision. JA: project administration. NC and JA: funding acquisition. All authors contributed to the article and approved the submitted version.

\section{FUNDING}

We acknowledge the financial assistance of BBSRC grant Advancing sustainable forage-based livestock production systems in Colombia (CoForLife) (BB/S01893X/1) and GROW Colombia from the UK Research and Innovation (UKRI) Global Challenges Research Fund (GCRF) (BB/P028098/1). The views expressed in this document cannot be taken to reflect the official opinions of these organizations.

\section{ACKNOWLEDGMENTS}

This work was implemented as part of the CGIAR Research Program (CRP) on Climate Change, Agriculture and Food Security (CCAFS), and the Livestock CRP, which are carried out with support from CGIAR Fund Donors and through bilateral funding agreements. For details, please visit https://ccafs.cgiar. org/donors. p. $43-46$.

5. Sejian V, Naqvi SM. Livestock and climate change: mitigation strategies to reduce methane production. In: G. Liu, editor. Greenhouse Gases-Capturing, Utilization and Reduction. London: InTech. (2012). doi: 10.5772/32014

6. Chandramoni SB, Jadhao CM, Tiwari CM, Khan MY. Energy metabolism with Particular reference to methane production in Muzaffarnagari sheep fed rations in roughage to concéntrate ratio. Anim Feed Sci Tech. (2000) 83:287-300. doi: 10.1016/S0377-8401(99)00132-7

7. Hatew B, Podesta SC, Van Laar H, Pellikaan WF, Ellis JL, Dijkstra $\mathrm{J}$, et al. Effects of dietary starch content and rate of fermentation on 
methane production in lactating dairy cows. J.Dairy Sci. (2015) 98:48699. doi: $10.3168 /$ jds.2014-8427

8. Niu M, Kebreab E, Hristov AN, Oh J, Arndt C, Bannink A, Crompton LA. Prediction of enteric methane production, yield, and intensity in dairy cattle using an intercontinental database. Glob Chang Biol. (2018) 24:336889. doi: $10.1111 / \mathrm{gcb} .14094$

9. Ortega-Gómez R, Castillo-Gallegos E, Jarillo-Rodríguez J, Escobar-Hernández $R$, Ocaña-Zavaleta E, de la Mora BV. Nutritive quality of ten grasses during the rainy season in a hot-humid climate and ultisol soil. Trop Subtrop Agroecosyst. (2011) 13:481-91.

10. Yan T, Mayne CS, Porter MG. Effects of dietary and animal factors on methane production in dairy cows offered grass silage-based diets. Int Congr Ser. (2006) 1293:123-6. doi: 10.1016/j.ics.2006.02.024

11. McAllister TA, Cheng K-J, Okine EK, Mathison GW. Dietary, environmental and microbiological aspects of methane production in ruminants. Can J Anim Sci. (1996) 76:231-43. doi: 10.4141/cjas96-035

12. Barahona R, Sánchez S. Limitaciones físicas y químicas de la digestibilidad de pastos tropicales y estrategias para aumentarla. Revis Corp. (2005) 6:6982. doi: 10.21930/rcta.vol6_num1_art:39

13. Tarazona AM, Ceballos MC, Naranjo JF, Cuartas CA. Factors affecting forage intake and selectivity in ruminants. Revis Colombiana Ciencias Pecuarias. (2012) 25:473-87. doi: 10.17533/udea.rccp

14. Richmond AS, Wylie ARG, Laidlaw AS, Lively FO. Methane emissions from beef cattle grazing on semi-natural upland and improved lowland grasslands. Animal. (2015) 9:130-7. doi: 10.1017/S1751731114002067

15. Gaviria-Uribe X, Naranjo-Ramírez JF, Bolívar-Vergara DM, BarahonaRosales R. Consumo y digestibilidad en novillos cebuínos en un sistema silvopastoril intensivo. Arch Zootec. (2015) 64:21-7. doi: 10.21071/az.v64i 245.370

16. Cuartas CA, Naranjo JF, Tarazona AM, Correa GA, Rosales RB. Dry matter and nutrient intake and diet composition in leucaena leucocephala-based intensive silvopastoral systems. Trop Subtrop Agroecosyst. (2015) 18:303-11.

17. Molina IC, Angarita EA, Mayorga OL, Chará J, Barahona R. Effect of leucaena leucocephala on methane production of lucerna heifers fed a diet based on cynodon plectostachyus. Livest Sci. (2016) 185:249. doi: 10.1016/j.livsci.2016.01.009

18. Arango J, Gutiérrez JF, Mazabel J, Pardo P, Enciso K, Burkart S, et al. Estrategias Tecnológicas Para Mejorar la Productividad y Competitividad de la Actividad Ganadera: Herramientas Para Enfrentar el Cambio Climático. Cali: Centro Internacional de Agricultura Tropical (2016). p. 58.

19. Peters M, Rao I, Fisher M, Subbarao G, Martens S, Herrero M, et al. Tropical forage based systems to mitigate greenhouse gas emissions. In: Hershey $\mathrm{CH}$, editor. Eco-Efficiency: From Vision to Reality. Cali: International Center for Tropical Agriculture (CIAT). (2013) p. 171-90.

20. Rao I, Peters M, Castro A, Schultze-Kraft R, White D, Fisher M, et al. LivestockPlus - the sustainable intensification of forage-based systems to improve livelihoods and ecosystem services in the tropics. Trop Grassl Forrajes Trop. (2015) 3:59-82. doi: 10.13140/RG.2.2.34128. 56322

21. Arango J, Ruden A, Martinez-Baron D, Loboguerrero AM, Berndt A, Chacón M, et al. Ambition meets reality: achieving GHG emission reduction targets in the livestock sector of Latin America. Front Sustain Food Syst. 4:65. doi: 10.3389/fsufs.2020.00065

22. Byrnes RC, Núñez J, Arenas L, Rao I, Trujillo C, Alvarez C, Arango J, Rasche F, Chirinda N. Biological nitrification inhibition by brachiaria grasses mitigates soil nitrous oxide emissions from bovine urine patches. Soil Biol Biochem. (2017) 107:156-63. doi: 10.1016/j.soilbio.2016.12.029

23. Landholm DM, Pradhan P, Wegmann P, Sánchez MAR, Salazar JCS, Kropp JP. Reducing deforestation and improving livestock productivity: greenhouse gas mitigation potential of silvopastoral systems in Caquetá. Environ Res Lett. (2019) 14:114007. doi: 10.1088/1748-9326/ab3db6

24. Vazquez E, Teutscherova N, Lojka B, Arango J, Pulleman M. Pasture diversification affects soil macrofauna and soil biophysical properties in tropical (silvo) pastoral systems. Agr Ecosyst Environ. (2020) 302:107083. doi: 10.1016/j.agee.2020.107083

25. Makkar HPS, Strnad I, Mittendorfer J. Proficiency testing of feed constituents: a comparative evaluation of European and developing country laboratories and its implications for animal production. J Agric Food Chem. (2016) 64:7679-87. doi: 10.1021/acs.jafc.6b02452

26. International Organization for Standardization (ISO). Animal Feeding Stuffs - Determination of Moisture and Other Volatile Matter Content. ISO 6496: Geneva, Switzerland. (1999)

27. Association of Official Analytical Chemists (AOAC). Official Methods of Analysis. 15th Edn. Arlington, VA: AOAC (1990).

28. Van Soest PJ, Robertson JB, Lewis BA. Methods for dietary fiber neutral detergent fiber and nonstarch polysaccharides in relation to animal nutrition. J Dairy Sci. (1991) 74:3583-97. doi: 10.3168/jds.S0022-0302(91)78551-2

29. International Organization for Standardization (ISO). International Organization for Standardization, ISO 9831. Animal feeding stuffs, animal products, and faeces or urine - Determination of gross calorific value Bomb calorimeter method. Geneva: Int. Org. Stand (1998).

30. Tilley J, Terry R. A two-stage technique for the in vitro digestion of forage crops. Grass Forage Sci. (1963) 18:10411. doi: $10.1111 / \mathrm{j} .1365-2494.1963 . t b 00335 . x$

31. Terrill TH, Rowan AM, Douglas GB, Barry TN. Determination of extractable and bound condensed tannin concentrations in forage plants, protein concentrate meals and cereal grains. J Sci Food Agric. (1992) 58:3219. doi: $10.1002 /$ jsfa. 2740580306

32. Lockyer DR. Methane emissions from grazing sheep and calves. Agr Ecosyst Environ. (1997) 66:11-8. doi: 10.1016/S0167-8809(97)00080-7

33. Murray PJ, Chadwi DC, Newbold CJ, Lockyer DR. Measurement of methane from grazing animals- the tunnel method. In: Makkar HP, Vercoe PE, editors. Measuring Methane Production from Ruminants. Dordrecht: Springer Netherlands.

34. Lopez S, Newbold CJ. Analysis of methane. In: Fao-Iaea HP, Makkar PV, editors. Measuring Methane Production From Ruminants. Dordrecht: Springer (2007). p. 10.

35. Cook BG, Pengelly BC, Schultze-Kraft R, Taylor M, Burkart S, Cardoso Arango JA, et al. Tropical Forages: an Interactive Selection Tool. 2nd ed. Cali; Addis Ababa: CIAT (International Center for Tropical Agriculture); ILRI (International Livestock Research Institute).

36. SAS Institute. User's Guide: Statistics Version 9.1. SAS Inst Inc: Cary, NC (2003).

37. Barahona R, Lascano CE, Cochran R, Morrill J, Titgemeyer EC. Intake, digestion, and nitrogen utilization by sheep fed tropical legumes with contrasting tannin concentration and astringency. J Animal Sci. (1997) 75:1633-40. doi: 10.2527/1997.7561633x

38. Khan NA, Booker H, Yu P. Effect of heating method on alteration of protein molecular structure in flaxseed: relationship with changes in protein subfraction profile and digestion in dairy cows. J Agric Food Chem. (2015) 63:1057-66. doi: 10.1021/jf503575y

39. Krizsan SJ, Ahvenjärvi S, Huhtanen P. A meta-analysis of passage rate estimated by rumen evacuation with cattle and evaluation of passage rate prediction models. J Dairy Sci. (2010) 93:5890-901. doi: 10.3168/jds.2010-3457

40. Allen MS. Effects of diet on short term regulation of feed intake by lactating dairy cattle. J Dairy Sci. (2000) 83:1598624. doi: 10.3168/jds.S0022-0302(00)75030-2

41. Bauman DE, Griinari JM. Regulation and nutritional manipulation of milk fat: low-fat milk syndrome. In: Mol JA, Clegg RA, editors. Biology of the Mammary Gland. New York, NY: Kluwer Academic Plenum Publishers. (2000). p. 240.

42. Tafaj M, Zebeli Q, Baes CH, Steingass H, Drochner W. A meta-analysis examining effects of particle size of total mixed rations on intake, rumen digestion and milk production in high yielding dairy cows in early lactation. Anim Feed Sci Tech. (2007) 138:137-61. doi: 10.1016/j.anifeedsci.2007.06.020

43. Jones RJ. Management of anti-nutritive factors - with special reference to leucaena. In: Gutteridge RC, Shelton HM, editors. Forage Tree Legumes in Tropical Agriculture. Wallingford: CABI (1994). p. 216-231.

44. García D, Wencomo H, Gonzáles M, Medina M, Cova L. Caracterización de diez cultivares forrajeros de leucaena leucocephala basada en la composición química y la degradabilidad ruminal. Revis MVZ Córdoba. (2008) 13:12941303. doi: $10.21897 / \mathrm{rmvz} .388$

45. Soltan YA, Morsy AS, Lucas RC, Abdalla AL. Potential of mimosine of Leucaena leucocephala for modulating ruminal nutrient 
degradability and methanogenesis. Anim Feed Sci Tech. (2017) 223:30-41. doi: 10.1016/j.anifeedsci.2016.11.003

46. Patra AK, Saxena J. Exploitation of dietary tannins to improve rumen metabolism and ruminant nutrition. J Sci Food Agric. (2011) 91:2437. doi: $10.1002 /$ jsfa. 4152

47. Montoya-Flores MD, Molina-Botero IC, Arango J, Romano-Muñoz JL, Solorio-Sánchez FJ, Aguilar-Pérez CF, et al. Effect of dried leaves of leucaena leucocephala on rumen fermentation, rumen microbial population, and enteric methane production in crossbred heifers. Animals. (2020) 10:300. doi: 10.3390/ani1002030

48. Piñeiro-Vázquez AT, Jiménez-Ferrer GO, Chay-Canul AJ, CasanovaLugo F, Díaz-Echeverría VF, Ayala-Burgos AJ, et al. Intake; digestibility; nitrogen balance and energy utilization in heifers fed low-quality forage and Leucaena leucocephala. Anim Feed Sci Tech. (2017) 228:194-201. doi: 10.1016/j.anifeedsci.2017.04.009

49. Minson DJ. The nutritive value of tropical pastures. J Austr Inst Agric Sci. (1971) 37:255-63.

50. Kennedy PM, Charmley E. Methane yields from Brahman cattle fed tropical grasses and legumes. Anim Prod Sci. (2012) 52:225-39. doi: 10.1071/AN11103

51. Murgueitio E, Chará J, Barahona R, Cuartas C, Naranjo J. Los sistemas silvopastoriles intensivos (SSPi), herramienta de mitigación y adaptación al cambio climático. Trop Subtrop Agroecosyst. (2014) 17:501-7.

52. Murgueitio E, Rosales RB, Estrada MXF, Orozco JDC, Herrera JER. Es posible enfrentar el cambio climático y producir más leche y carne con sistemas silvopastoriles intensivos. Ceiba. (2016) 54:23-30. doi: 10.5377/ceiba.v54i1.2774

53. Chará J, Rivera J, Barahona R, Murgueitio E, Deblitz C, Reyes E, Zuluaga A. Intensive silvopastoral systems: economics and contribution to climate change mitigation and public policies. In: Integrating Landscapes: Agroforestry for Biodiversity Conservation and Food Sovereignty. Cham: Springer (2017). p. 395-416. doi: 10.1007/978-3-319-69371-2_16

54. Rivera JE, Chará J, Barahona R. $\mathrm{CH}_{4}, \mathrm{CO}_{2}$ and $\mathrm{N}_{2} \mathrm{O}$ emissions from grasslands and bovine excreta in two intensive tropical dairy production systems. Agrofor Syst. (2019) 93:915-28. doi: 10.1007/s10457-018-0187-9

55. Rivera JE, Chará J, Murgueitio E, Molina JJ, Barahona R. Feeding leucaena to dairy cows in intensive silvopastoral systems in Colombia and Mexico. Trop Grassl Forrajes Trop. (2019) 7:370-4. doi: 10.17138/tgft(7)370-374

56. Cook BG, Pengelly BC, Schultze-Kraft R, Taylor M, Burkart S, CardosArango JA, et al. Tropical Forages: an Interactive Selection Tool. 2nd Edn. CIAT (International Center for Tropical Agriculture) and ILRI (International Livestock Research Institute).

57. Dalzell SA. Cultivares de Leucaena: liberaciones actuales y oportunidades futuras. Pastizales Trop Forrajes Trop. (2019) 7:56-64. doi: 10.17138/tgft(7)56-64

58. Pinares-Patiño CS, Franco FR, Molano G, Kjestrup H, Sandoval E, MacLean S, et al. Feed intake and methane emissions from cattle grazing pasture sprayed with canola oil. Livest Sci. (2016) 184:7-12. doi: 10.1016/j.livsci.2015.11.020

59. Huhtanen PM, Ramin E, Cabezas-Garcia H. Effects of ruminal digesta retention time on methane emissions: a modelling approach. Anim Prod Sci. (2016) 56:501-6. doi: 10.1071/AN15507

60. Hristov AN, Ott T, Tricarico J, Rotz A, Waghorn G, Adesogan A, et al. Mitigation of methane and nitrous oxide emissions from animal operations: III. A review of animal management mitigation options. J Anim Sci. (2013) 91:5095-113. doi: 10.2527/jas.2013-6585

61. Maccarana L, Cattani M, Tagliapietra F, Bailoni L, Schiavon S. (2016). Influence of main dietary chemical constituents on the in vitro gas and methane production in diets for dairy cows. J Anim Sci Biotechno. 7:54. doi: 10.1186/s40104-016-0109-5

62. Beauchemin KA, Ungerfeld EM, Eckard RJ, Wang M. Review: fifty years of research on rumen methanogenesis: lessons learned and future challenges for mitigation. Animal. (2020) 14:s2-s16. doi: 10.1017/S1751731119003100

63. Mieres J, Olivera L, Martino D, La Manna A, Fernándes E, Palermo R, et al. Methane emissions from holstein heifers grazing contrasting pastures in Uruguay. In: Proceedings of the 3rd International Methane and Nitrous Oxide Mitigation Conference. Beijing (2002)

64. Ellis JL, Dijkstra J, France J, Parson AJ, Edwards GR, Rasmussen S, et al. Effect of high-sugar grasses on methane emissions simulated using a dynamic model. J Dairy Sci. (2012) 95:272-85. doi: 10.3168/jds.2011-4385
65. Montenegro J, Barrantes E, DiLorenzo N. Methane emissions by beef cattle consuming hay of varying quality in the dry forest ecosystem of Costa Rica. Livest Sci. (2016) 193:45-50. doi: 10.1016/j.livsci.2016. 09.008

66. Molina IC, Donneys G, Montoya S, Rivera JE, Villegas G, Chará J, et al. La inclusión de leucaena leucocephala reduce la producción de metano de terneras Lucerna alimentadas con cynodon plectostachyus y Megathyrsus maximus. Livestock Res Rur Dev. (2015) 27:96.

67. Kurihara M, Magner T, Hunter RA, McCrabb GJ. Methane production and energy partition of cattle in the tropics. Br J Nutr. (1999) 81:22734. doi: $10.1017 /$ S0007114599000422

68. Boadi DA, Wittenberg KM. Methane production from dairy and beef heifers fed forages differing in nutrient density using the sulphur hexafluoride (SF6) tracer gas technique. Can J Anim Sci. (2002) 82:201-6. doi: 10.4141/A01-017

69. Archimède $H$, Eugène $M$, Magdeleine $C$, Boval $M$, Martin $C$, Morgavi D, et al. Comparison of methane production between C3 and C4 grasses and legumes. Anim Feed Sci Tech. (2011). 166-7:59-64. doi: 10.1016/j.anifeedsci.2011.04.003

70. Barahona R, Lascano CE, Cochran RC, Morril JL. Efecto del manejo poscosecha del forraje y la adición de polietilenglicol en la concentración y la astringencia de taninos condensados en leguminosas tropicales. Pasturas Trop. (1996) 18:41-6.

71. Huang XD, Liang JB, Tan HY, Yahya R, Khamseekhiew B, Ho YW. Molecular weight and protein binding anity of Leucaena condensed tannins and their effects on in vitro fermentation parameters. Anim Feed Sci Technol. (2010) 159:81-7. doi: 10.1016/j.anifeedsci.2010.05.008

72. Ojeda Á, Obispo N, Gil JL, Matute I. Perfil cualitativo de metabolitos secundarios en la fracción comestible de especies leÑosas seleccionadas por vacunos en un bosque semicaducifolio. Pastos Forrajes. (2015) 38:64-72.

73. Patra A, Park T, Kim M, Yu Z. Rumen methanogens and mitigation of methane emission by antimethanogenic compounds and substances. J Anim Sci Biotechnol. (2017) 8:13. doi: 10.1186/s40104-017-0145-9

74. Barahona R. Condensed Tannins in Tropical Forage Legumes: Their Characterization and Study of Their Nutritional Impact From the Standpoint of Structure-Activity Relationships. (Ph.D. Thesis). University of Reading (1999).

75. Lassey KR. Livestock methane emission: From the individual grazing animal through national inventories to the global methane cycle. Agric For Meteorol. (2007) 142:120-32. doi: 10.1016/j.agrformet.2006.03.028

76. Blaxter KL, Clapperton JL. Prediction of the amount of methane produced by ruminants. Br J Nut. (1965) 19:511-22. doi: 10.1079/BJN19650046

77. Intergovernmental Panel on Climate Change (IPCC). Summary for policymakers. In: Climate Change and Land: An IPCC Special Report on Climate Change, Desertification, Land Degradation, Sustainable Land Management, Food Security, and Greenhouse Gas Fluxes in Terrestrial Ecosystems. Geneva: IPCC (2019).

78. Gavrilova O, Leip A, Dong H, MacDonald JD, Gomez Bravo CA, Amon B, et al. Emissions from livestock and manure management. In: Calvo Buendia E, Tanabe K, Kranjc A, Baasansuren J, FukudaM, Ngarize S, et al., editors. 2019 Refinement to the 2006 guidelines for National Greenhouse Gas Inventories. Agriculture, Forestry and Other Land Use. Geneva: IPCC (2019). p. 10.110.171 .

79. Molina-Botero IC, Montoya-Flores MD, Zavala-Escalante LM, BarahonaRosales R, Arango J, Ku-Vera JC. Effects of long-term diet supplementation with gliricidia sepium foliage mixed with Enterolobium cyclocarpum pods on enteric methane, apparent digestibility, and rumen microbial population in crossbred heifers. J Anim Sci. (2019) 97:1619-33. doi: 10.1093/jas/skz067

80. Chuntrakort P, Otsuka M, Hayashi K, Takenaka A, Udchachon S, Sommart $K$. The effect of dietary coconut kernels, whole cotton seeds and sunflower seeds on the intake, digestibility and enteric methane emissions of Zebu beef cattle fed rice straw-based diets. Livest Sci. (2014) 161:809. doi: 10.1016/j.livsci.2014.01.003

81. Hammond KJ, Humphries DJ, Westbury DB, Thompson A, Crompton LA, Kirton $\mathrm{P}$, et al. The inclusion of forage mixtures in the diet of growing dairy heifers: impacts on digestion, energy utilization, and methane emissions. Agr Ecosyst Environ. (2014) 197:88-95. doi: 10.1016/j.agee.2014.07.016

82. Molina IC, Arroyave J, Valencia S, Barahona R, Aguilar C, Ayala A, et al. Effects of tannins and saponins contained in foliage of gliricidia sepium and pods of enterolobium cyclocarpum on fermentation, methane emissions and 
rumen microbial population in crossbred heifers. Anim Feed Sci Technol. (2019) 251:1-11. doi: 10.1016/j.anifeedsci.2019.01.011

83. Poppi DP, Quigley SP, Silva SR. Challenges of beef cattle production from tropical pastures. $R$ Bras Zoot. (2018) 47:e20160419. doi: 10.1590/rbz4720160419

84. Petty SR, Poppi DP. Effect of muddy conditions in the field on the liveweight gain of cattle consuming Leucaena leucocephala/Digitaria eriantha pastures in north-west Australia. Aust J Exp Agric. (2008) 48:81820. doi: 10.1071/EA07416

85. McLennan SR. Final Report B.NBP.0391, Optimising Growth Paths of Beef Cattle in Northern Australia for Increased Profitability. Meat and Livestock Australia (2014). p. 182. Available online at: https://www. mla.com.au/research-and-development/search-rd-reports/final-reportdetails/Productivity-On-Farm/Optimising-growth-paths-of-beef-cattle-innorthern-Australia-for-increased-profitability/372\#
86. Ideam PMC. Primer Informe Bienal de Actualización de Colombia. Bogotá: IDEAM (2015)

Conflict of Interest: The authors declare that the research was conducted in the absence of any commercial or financial relationships that could be construed as a potential conflict of interest.

Copyright (๑ 2020 Gaviria-Uribe, Bolivar, Rosenstock, Molina-Botero, Chirinda, Barahona and Arango. This is an open-access article distributed under the terms of the Creative Commons Attribution License (CC BY). The use, distribution or reproduction in other forums is permitted, provided the original author $(s)$ and the copyright owner(s) are credited and that the original publication in this journal is cited, in accordance with accepted academic practice. No use, distribution or reproduction is permitted which does not comply with these terms. 